\title{
Assessment of Gender, Location and Socio-Economic Status on Students' Performance in Senior Secondary Certificate Examination in Mathematics
}

\author{
Patrick U. Osadebe ${ }^{1} \&$ Diakeleho-Edjere Oghomena ${ }^{1}$ \\ ${ }^{1}$ Delta State University, Abraka, Nigeria \\ Correspondence: Patrick U. Osadebe, Delta State University, Abraka, Nigeria. Tel: 80-3577-6610. E-mail: \\ drosadebeuzo@gmail.com
}

Received: February 10, 2018

Accepted: April 15, $2018 \quad$ Online Published: July 28, 2018

doi:10.5539/ies.v11n8p98

URL: https://doi.org/10.5539/ies.v11n8p98

\begin{abstract}
This study assessed the demographic characteristics of students' performance in Mathematics in senior secondary Certificate Examination in Delta Central Senatorial District of Delta State. The purpose of the study is to assess the relationship between gender, location, socio-economic status and students' performance in Mathematics in Senior Secondary Certificate Examination. The ex-post facto research design was used for the study. The population of the study is $15,170 \mathrm{SS} 3$. A sample of 759 students was randomly selected from the total population using simple random sampling technique of balloting and stratified random sampling technique. Four research questions and four hypotheses were raised to guide the study. The instrument used for the study was a 40-item multiple choice senior secondary Mathematics Achievement test (SSMAT). Multiple regressions were used for the analysis. The study established that gender and socio-economic status contributed to students' performance in Mathematics in senior secondary certificate examination. Recommendation was made based on the findings of the study.
\end{abstract}

Keywords: assessment, gender, location, socio-economic status, performance

\section{Introduction}

Mathematics, as a formal area of teaching and learning, was developed about 5000 years ago by the Sumerians. However, the roots of Mathematics go back much more than 5000 years. Mathematics is the science that deals with the logic of shapes, quantity and arrangement (Hom, 2013). Turnbull, Lea, Parkinson, Phillips, Francis, Webb and Bull (2015) defined Mathematics as the science of numbers and shapes. It involves calculation, computation, measurement, quantity and magnitude. It is exact, precise, systematic and logical. The subject reveals hidden patterns that help us to understand the world around us. Umameh (2011) believes Mathematics helps the individual to understand the environment and to give accurate account of the physical phenomena around every person. Fatima (n. d) sees Mathematics as a science whose subject matter is special forms and qualitative relationships of the real world. A. Udonsa and O. Udonsa (2015) defined Mathematics as the study of qualitative relations or the science of structure, order, numbers, space and relations about counting, measuring, describing of shapes and objects. Branches of Mathematics according to Turnbull et al. (2015) include Arithmetic, Algebra, Geometry, Trigonometry, Calculus and Discrete Mathematics.

The history of modern Mathematics in Nigeria could be traced to the introduction of arithmetic by the European Missionaries into the Nigerian School System. A. Udonsa and O. Udonsa (2015) explains that prior to the advent of the European Missionaries in the country, there was an indigenous system of Mathematics which was expressed in the form of counting and a variety of human experiences was used to promote practice and dexterity in enumeration. With the coming of the missionaries however, the branch of Mathematics called arithmetic was introduced so as to inculcate counting and numeracy skills which were mostly needed to facilitate business transactions and other demands of the age. During the twentieth century, high precedence was given to Mathematics as it became considered to be an important foundation for scientific, technological and economic development of the Nigerian society. Ale (2004) stated unequivocally that a country will find it extremely difficult to produce graduates in the field of engineering, science and technology unless it lays a solid foundation in mathematical science for students of all categories. Salman, Mohammed, Ogunlade and Ayinla (2012) describe Mathematics as the queen and servant of all school subjects, since it cuts across the school curricula. This explains 
why Mathematics, as a school subject, affects all aspects of human life, cutting across economics, political science, geography, science and technology etc., as it is centered on the use of numbers, an integral component of every aspect of knowledge. Furthermore, Mathematics is the language used to describe the problems arising in most branches of science and technology. Based on the notion that improved mathematical skill would enhance the development of the country and the quest of realizing the goals and objectives of education in Nigeria, prominence was given to the study of Mathematics in schools in Nigeria as one of the core subjects which must be passed at credit level to gain admission for further studies in any tertiary institution in the science based courses like Mathematics, physics, chemistry, biology, statistics, engineering, economics, medical sciences, to mention but a few. Unfortunately, a lot of Nigerian students of the $21^{\text {st }}$ century have demonstrated little or no enthusiasm towards studying Mathematics, and this is perhaps the reason many students perform poorly in the subject.

Research findings, publications of government and examinations bodies over the years have shown that there is a poor level of Mathematics attainment by students at every level of education in Nigeria, particularly at the Senior Secondary School level (Ajayi, 2002; Nwokocha \& Amadike, 2005; Adepoju \& Oluchukwu, 2011; Ezeudu \& Obi, 2013; Ezeudu, Gbendu, \& Umeifekwem, 2014). A review of students' performance in Mathematics in Delta State over the period 2006 - 2012 in Senior Secondary Certificate Examinations (SSCE) conducted by the West African Examinations Council (WAEC) indicate a general unsatisfactory state of affairs, as reflected by the poor performance of students in Mathematics. Statistics published by the Education Resource Centre (2014) of the Delta State Ministry of Basic and Secondary Education shows that only $15.90 \%$ of 31,117 (2006), $26.10 \%$ of 24,960 (2007), $41.0 \%$ of 25,859 (2008), $42.10 \%$ of 29,761 (2009), $36.30 \%$ of 38,705 (2010), $38.70 \%$ of 51,042 (2011) and 49.10\% of 56,443 (2012) of the candidates who enrolled for Mathematics in the Senior Secondary Certificate Examination, passed. This level of poor Mathematics performance was the major focus of discussions at the fiftieth Annual Conference of the Mathematical Association of Nigeria (MAN) held in Asaba. The Mathematical Association of Nigeria (2013) identified the possible causes of poor performance in Mathematics to be students, teachers and government related. The Association also identified poor teaching facilities, inadequate and poorly trained teachers, parental laxity, underfunding, gender difference, school location, politics, socio-economic differences, etc., as factors that are affecting students' performance in Mathematics in Nigeria. The MAN emphasised on the need to give attention to the impact demographic characteristics has on students' performance in Mathematics in Senior Secondary Certificate Examination, as a way to reducing the level of poor performance in Mathematics. As a result, the researcher believes there is an urgent need for the assessment of these variables viz-a-viz how they impinge on performance, since situations are not static. The central focus in this study therefore, is the assessment of demographic characteristics of students' performance in Mathematics in Senior Secondary Certificate Examination (SSCE).

\subsection{Research Questions}

The following research questions guided the study:

(i) What is the relationship between gender, location, socio-economic status and students' performance in Mathematics in Senior Secondary Certificate Examination?

(ii) What is the relationship between gender and students' performance in Mathematics in Senior Secondary Certificate Examination?

(iii) What is the relationship between location and students' performance in Mathematics in Senior Secondary Certificate Examination?

(iv) What is the relationship between socio-economic status and students' performance in Mathematics in Senior Secondary Certificate Examination?

\subsection{Hypotheses}

The following hypotheses were tested at 0.05 level of significance.

(i) There is no significant relationship between gender, location, socio-economic status and students' performance in Mathematics in Senior Secondary Certificate Examination.

(ii) There is no significant relationship between gender and students' performance in Mathematics in Senior Secondary Certificate Examination.

(iii) There is no significant relationship between location and students' performance in Mathematics in Senior Secondary Certificate Examination.

(iv) There is no significant relationship between socio-economic status and students' performance in Mathematics in Senior Secondary Certificate Examination. 


\section{Method}

The ex-post facto research design was employed for the study. Ex-post facto design was used because the researcher's aim was to assess the existing differences in the performance of students in Mathematics in the Senior Secondary Certificate Examination. The population of the study comprised all the 179 Delta State-owned Public Secondary Schools in the Delta Central Senatorial District of Delta State (Delta State Ministry of Education, Asaba), with a total of 56,735 SS students for the 2016 session drawn from both the urban and rural areas of the Senatorial District. Among the 56,735 SS students are a total of 15,170 students who comprised the SS 3 students. The 15,170 SS 3 students are made up of 3,187 males and 3,255 female students from 50 urban schools, and 4,402 males and 4,326 females from 129 rural schools in the Delta Central Senatorial District of Delta State. Out of the total population of 15,170 SS 3 students for the study, 7,589 are males and 7,581 are females from both urban and rural areas respectively across the eight Local Government Areas that constitute the Senatorial District.

A sample size of five percent $(5 \%)$ of the total population $(15,170)$ of SS 3 students is desired for the study. Five percent of 15,170 equal 759 SS 3 students. This was the total number of students randomly drawn from the 179 state-owned public secondary schools in the Delta Central Senatorial District of Delta State for the study (see Appendix III, for the list of secondary schools in the Senatorial District). The average number of students per school is the population of study $(15,170)$ divided by the number of schools $(179)$ in the Senatorial District. That is 15,170 divided by 179 , which gives 85 students approximately, per school. The total number of schools needed for the study equals the sample size (759) divided by the average number of students per school (85). Thus, the number of schools needed for the study is nine (9) schools approximately. Therefore, out of the 179 schools in the area of study, nine were selected through simple random sampling by balloting and stratified random sampling techniques. On the basis of the above, the sample of the study is $759 \mathrm{SS} 3$ students randomly selected from nine urban and rural secondary schools respectively.

The instrument used for the collection of data for the study is the Senior Secondary Mathematics Achievement Test (SSMAT). The SSMAT is a multiple choice objective test of 40-items adapted from the Senior Secondary Certificate Examination (SSCE) past questions (from 2009 to 2015 academic sessions). This procedure was employed because Osadebe (2015) and Akabogu (2004) posit that past examination questions such as the WAEC conducted SSCE are regarded as standard measures for instructional situations and are generally alid and reliable. The SSMAT instrument covered the content of Mathematics at the knowledge, comprehension, application, analysis, synthesis and evaluation levels of the cognitive domain of the Bloom's taxonomy of education objectives contained in the senior secondary school Mathematics curriculum. The test blue print or table of specification (See Appendix VI) guided the researcher in the compilation of the test items. The SSMAT consisted of two sections, A and B. Section A was demographic data of the respondents. Section B of the instrument is a 40-item multiple choice objective test. There are five options (A, B, C, D, E) for each item made up of one correct answer (key) and four wrong answers (distracters). The respondents were required to tick $(\sqrt{ })$ for the best alternative from $A$ to $E$ that correctly answers the question given in each item.

The validity of the test instrument was established by subjecting the test items to expert screening. Among the experts who screened the test instrument is my research supervisor and two other lecturers in the Department of Guidance and Counselling and in particular, Measurement and Evaluation Unit, to ensure both face and content validity. The estimate of reliability of the Senior Secondary Mathematics Achievement Test (SSMAT) was determined through Kuder Richardson formula $20\left(\mathrm{~K}-\mathrm{R}_{20}\right)$. Copies of the final test were administered to a randomly drawn sample of 30 respondents. Each either passes an item with (1) or fails with (0). The $\mathrm{K}-\mathrm{R}_{20}$ helped to establish the internal consistency of the Senior Secondary Mathematics Achievement Test. The $\mathrm{K}-\mathrm{R}_{20}$ correlation coefficient was calculated using IBM SPSS. Thus a reliability estimate of .85 was obtained. This helped to establish the internal consistency of the SSMAT. The details are as shown in Appendix I. On the basis of the results, the test instrument was judged to be reliable.

The list of all the State-owned public Secondary Schools in Delta State Senatorial District was obtained from the Delta State Ministry of Education, Asaba, upon application to the Permanent Secretary (See Appendix III). The researcher personally paid visits to the nine sampled secondary schools used for the study, solicited and obtained permission from the various principals to use their schools for the study (See Appendix IX). The Senior Secondary Mathematics Achievement Test (SSMAT), the instrument for the study, was administered to the 759 SS 3 students sampled from the nine randomly selected secondary schools. The teachers of Mathematics in the sampled schools assisted the researcher in the administration of the instrument in order to avoid any test malpractice. As soon as the administration was completed, the teachers immediately collected the responses from the students and handed over the parcels of completed tests to the researcher under seal for marking and coding. 
The data elicited from the field were analysed and presented in tabular format. The scores of the respondents were graded over 40 to determine the Mean (X). On the basis of the mean, the researcher calculated the Standard Deviation (SD) and tested the significance of the performance of gender (male and female), location (urban and rural), and socio-economic status (high and low) on Senior Secondary Certificate Examination in Mathematics. The major statistical technique employed in the study is the standard multiple regression analysis. Coefficient of determination and percentage were used to determine the amount of contribution the independent variables made to the dependent variable, while F-test was used to test the hypotheses at the 0.05 level of significance.

\section{Results}

\section{Research Questions 1}

What is the relationship between gender, location, socio-economic status and students' performance in Mathematics Senior Secondary Certificate Examination?

Table 1. Correlation between gender, location, socioeconomic status and students' performance in Mathematics Senior Secondary School Certificate Examination

\begin{tabular}{lccccc}
\hline \multicolumn{5}{c}{ Model Summary } \\
\hline Variables & $\mathrm{R}$ & $\mathrm{R}^{2}$ & $\mathrm{Adj} \mathrm{r}^{2}$ & $\mathrm{SEE}$ & $\mathrm{R}^{2} \%$ \\
\hline $\begin{array}{l}\text { Performance (Constant) } \\
\text { Gender }\end{array}$ & & & & & \\
$\begin{array}{l}\text { Location } \\
\text { Socio-Economic Status }\end{array}$ & 0.25 & 0.06 & 0.06 & 4.50 & 6 \\
\hline
\end{tabular}

Table 1 shows the adjusted coefficient of determination $\left(\mathrm{R}^{2}\right)$ value as 0.06 . This shows that $6 \%$ of variance in students' performance in Mathematics in Senior Secondary Certificate Examination is attributed to the collective impact of all three independent variables - gender, location and socio-economic status of the parents of the students.

\section{Research Questions 2}

What is the relationship between gender and students' performance in Mathematics Senior Secondary Certificate Examination?

Table 2. Correlation between gender and students' performance in mathematics in senior secondary school certificate examination

\begin{tabular}{llllll}
\hline \multicolumn{5}{c}{ Model Summary } \\
\hline Variable & $\mathrm{R}$ & $\mathrm{r}^{2}$ & Adj r & See & $\mathrm{r}^{2} \%$ \\
\hline $\begin{array}{l}\text { Performance } \\
\text { Gender }\end{array}$ & 0.21 & 0.04 & 0.04 & 4.55 & 4 \\
\hline
\end{tabular}

Table 2 shows the adjusted coefficient of determination $\left(\mathrm{r}^{2}\right)$ value as 0.04 . This indicates that $4 \%$ of variance in students' performance in Mathematics in Senior Secondary Certificate Examination is attributed to the impact of gender. Therefore, gender contributed $4 \%$ to the performance of students in Mathematics.

Research Questions 3

What is the relationship between location and students' performance in Mathematics in Senior Secondary Certificate Examination?

Table 3. Correlation between location and students' performance in mathematics in senior secondary school certificate examination

\begin{tabular}{llllll}
\hline & \multicolumn{7}{c}{ Model Summary } & \\
\hline Variable & $\mathrm{R}$ & $\mathrm{r}^{2}$ & Adj r $^{2}$ & See & $\mathrm{r}^{2} \%$ \\
\hline $\begin{array}{l}\text { Performance } \\
\text { Location }\end{array}$ & 0.03 & 0.00 & 0.00 & 4.65 & 0 \\
\hline
\end{tabular}

Table 3 shows the adjusted coefficient of determination $\left(\mathrm{r}^{2}\right)$ value as 0.00 . This shows that $0 \%$ of variance in 
students' performance in Mathematics in Senior Secondary Certificate Examination is attributed to the impact of location. Therefore, location contributed $0 \%$ to the performance of students in Mathematics.

\section{Research Questions 4}

What is the relationship between socio-economic status and students' performance in Mathematics in Senior Secondary Certificate Examination?

Table 4. Correlation between socio-economic status and students' performance in mathematics in senior secondary school certificate examination

\begin{tabular}{lccccc}
\hline \multicolumn{6}{c}{ Model Summary } \\
\hline Variable & $\mathrm{R}$ & $\mathrm{r}^{2}$ & $\operatorname{Adj~}^{2}$ & See & $\mathrm{r}^{2} \%$ \\
\hline $\begin{array}{l}\text { Performance } \\
\text { Socio-Economic Status }\end{array}$ & 0.13 & 0.02 & 0.02 & 4.60 & 2 \\
\hline
\end{tabular}

Table 4 shows the adjusted coefficient of determination $\left(\mathrm{r}^{2}\right)$ value as 0.02 . This shows that $2 \%$ of variance in students' performance in Mathematics in Senior Secondary Certificate Examination is attributed to the impact of socio-economic status of students' parents. Therefore, socio-economic status contributed $2 \%$ to the performance of students in Mathematics.

Hypotheses 1

There is no significant relationship between gender, location, socioeconomic status and students' performance in Senior Secondary Certificate Examination in Mathematics.

Table 5. Regression of gender, location, socio-economic status and students' performance in mathematics in senior secondary school certificate examination

Significance: $\mathrm{P}<0.05$.

\begin{tabular}{llllll}
\hline \multicolumn{5}{c}{ ANOVA } \\
\hline & SS & Df & MS & F & P \\
\hline Regression & 932.80 & 3 & 310.93 & 15.35 & $0.00^{*}$ \\
Residual & 14320.86 & 707 & 20.26 & & \\
Total & 15253.67 & 710 & & & \\
\hline
\end{tabular}

Table 5 shows that $\mathrm{F}(3,707)=15.35, \mathrm{p}<0.05$. This indicates a statistically significant correlation among gender, location, socio-economic status and students' performance in Mathematics in Senior Secondary Certificate Examination. The null hypothesis is therefore rejected and the alternative hypothesis, that there is a significant relationship between gender, location, socioeconomic status and students' performance in Mathematics in Senior Secondary Certificate Examination, holds true.

Hypotheses 2

There is no significant relationship between gender and students performance in Mathematics in Senior Secondary Certificate Examination.

Table 6. Regression of gender and student's performance in mathematics in senior secondary school certificate examination

Significance: $\mathrm{P}<0.05$.

\begin{tabular}{llllll}
\hline \multicolumn{5}{c}{ ANOVA } \\
\hline & SS & Df & MS & F & P \\
\hline Regression & 731.16 & 1 & 731.16 & 35.37 & $0.00^{*}$ \\
Residual & 15650.84 & 757 & 20.67 & & \\
Total & 16381.99 & 758 & & & \\
\hline
\end{tabular}

Table 6 shows that $\mathrm{F}(1,757)=35.37, \mathrm{p}<0.05$. This indicates a statistically significant correlation between gender 
and students' performance in Mathematics in Senior Secondary Certificate Examination. The null hypothesis is therefore rejected and the alternative hypothesis, that there is a significant relationship between gender and students performance in Mathematics in Senior Secondary Certificate Examination, holds true.

\section{Hypotheses 3}

There is no significant relationship between location and students' performance in Mathematics in Senior Secondary Certificate Examination.

Table 7: Regression of location and students' performance in mathematics in senior Secondary School Certificate Examination

\begin{tabular}{llllll}
\hline \multicolumn{7}{c}{ ANOVA } \\
\hline & SS & Df & MS & F & P \\
\hline Regression & 16.97 & 1 & 16.97 & 0.79 & 0.38 \\
Residual & 16365.03 & 757 & 21.62 & & \\
Total & 16381.99 & 758 & & & \\
\hline
\end{tabular}

Significance: $\mathrm{P}<0.05$.

Table 7 shows that $F(1,757)=0.79, p>0.05$. This indicates that there is no statistically significant relationship between location and students' performance in Mathematics in Senior Secondary Certificate Examination. The null hypothesis is therefore accepted. This means that the alternative hypotheses, that there is a statistically significant relationship between location and students' performance in Mathematics in Senior Secondary Certificate Examination, does not hold true.

Hypotheses 4

There is no significant relationship between socioeconomic status and students' performance in Mathematics in Senior Secondary Certificate Examination.

Table 8. Regression of socioeconomic status and student's performance in mathematics in senior secondary certificate examination

Significance: $\mathrm{P}<0.05$.

\begin{tabular}{llllll}
\hline \multicolumn{5}{c}{ ANOVA } \\
\hline & SS & Df & MS & F & P \\
\hline Regression & 250.45 & 1 & 250.45 & 35.37 & $0.00^{*}$ \\
Residual & 15003.22 & 709 & 21.16 & & \\
Total & 15253.67 & 710 & & & \\
\hline
\end{tabular}

Table 8 shows that $\mathrm{F}(1,709)=35.37, \mathrm{p}<0.05$. This indicates that there is a statistically significant relationship between socio-economic status and students' performance in Mathematics in Senior Secondary Certificate Examination. The null hypothesis is therefore rejected and the alternative hypothesis, that there is a significant relationship between socio-economic status and students' performance in Mathematics in Senior Secondary Certificate Examination, holds true.

\section{Discussion}

The findings are discussed in relation to the research questions and hypotheses. The findings from the research questions show that gender and socio-economic status have statistically significant effects on students' performance in Senior Secondary Certificate Examination in Mathematics. However, location has no statistically significant effect on students' performance in Mathematics.

The findings on hypotheses 1 revealed that there is a statistically significant relationship between gender, location, socio-economic status and students' performance in Senior Secondary Certificate Examination in Mathematics. This means that students' performance in Senior Secondary Certificate Examination in Mathematics is affected by a combined impact of these variables. This is evident on the Model Summary on Table 5 which shows that $6 \%$ of variance in students' performance in Mathematics is due to these variables. This agrees with Alkhadrawi (2015), Owoeye and Yara (2011), and Ghaemi and Yazdanpanah (2014) whose respective studies show that gender, 
location and socio-economic status respectively have statistically significant relationship on students' performance in Mathematics.

The findings on hypotheses 2 showed that there is a statistically significant relationship between gender and students' performance in Senior Secondary Certificate Examination in Mathematics. The Model Summary on Table 6 shows that $4 \%$ of variance in students' performance in Mathematics was due to the impact of gender. This position agrees with Owoeye and Yara (2011) who posited that gender has a statistically significant relationship with performance and disagrees with Orubu (2007), who posited that gender has no significant relationship with performance in Mathematics.

The results of hypotheses 3 show that there is no statistically significant relationship between location and students' performance in Senior Secondary Certificate Examination in Mathematics. The Model Summary on Table 7 shows that location impacted 0\% variance in students' performance in Senior Secondary Certificate Examination in Mathematics. This agrees with Zappala and Considine (2002), Ezeudu (2003), Ezeudu and Obi (2013) as well as Ezeudu et al. (2014), all of whom posit that there is no significant difference between location and students' performance in Mathematics.

The findings of hypotheses 4 show a statistically significant relationship between socio-economic status and students' performance in Senior Secondary Certificate Examination in Mathematics. The Model Summary on Table 8 show that socio-economic status accounts for $2 \%$ of variance in students' performance in Senior Secondary Certificate Examination in Mathematics. This finding is in agreement with Orubu (2007) who posited that positive and significant relationships were found to exist between students' parent's income, educational background, family types and performance in Mathematics. The finding also agrees with Ghaemi and Yazdanpanh (2014) who found that socio-economic factors constitute the main cause of inequality of students in schools and other educational systems.

\section{Conclusion and Recommendations}

This study confirms the view by many experts that gender and socio-economic status of parents impact upon students' performance in Senior Secondary Certificate Examination in Mathematics. However, the findings contradict the view that performance in Senior Secondary Certificate Examination is influenced by the location of the student. Although the findings of the study particularly relate to the Delta Central Senatorial District of Delta State, they could be referred to in judging students' performance in Senior Secondary Certificate Examination in Mathematics in other parts of Delta State.

Based on the findings of the study, the following recommendations are proffered:

1) Students, irrespective of their gender should be equally encouraged to study Mathematics since it is basic for making progress in every area of life.

2) Parents should make concerted effort to improve on their socio-economic status by diversifying their sources of income so as to be able to meet the required financial pressure of training their children through Senior Secondary School.

\section{References}

Abbott, S. (Ed.) (2015). Assessment: The glossary of education reform. Retrieved from http://edglossary.org/assessment

Abiam, P. O., \& Odok, J. K. (2006). Factors in students' achievement in different branches of secondary school Mathematics. Journal of Education and Technology, 1, 161-168.

Achelles, C. M., \& Finn, J. D. (1990). Answers and questions about class size; A statewide experiment. American Educational Research Journal, 23(3), 2-20.

Adepoju, T. L., \& Oluchukwu, E. E. (2011). A study of secondary school students' academic performance at the senior school certificate examinations and implications for educational planning and policy in Nigeria. African Research Review, 5(6), 314-333. https://doi.org/10.4314/afrrev.v5i6.26

Ajai, J. T., \& Imoko, B. I. (2015). Gender differences in Mathematics achievement and retention scores: A case of problem-based learning method. International Journal of Research in Education and Science (IJRES), 1(1), 45-50. https://doi.org/10.21890/ijres.76785

Ajayi, I. A. (2002). Resource factors as correlates of secondary school effectiveness in Ekiti State, Nigeria. Journal of Counselling and Applied Psychology, 1(1), 109-115.

Akabogu, J. U. (2004). Effect of location on students achievement in reading comprehension. International 
Journal of Educational Research. Faculty of Education, University of Nigeria, Nsukka.

Ale, S. (2004). Weak maths base threatens production of engineers and scientists. Vanguard, 23.

Alkhadrawi, A. (2015). Gender difference in math and science choices and preferences ( $\mathrm{Ph}$. D. thesis, University of Toledo, Toledo, Ohio, USA).

Amannah, C. I., Okwelle, P. C., \& Wokocha, C. M. (2004). Influence of school location and class size on academic performance of students in public secondary schools in Rivers State, Nigeria. African Social and Policy Journal, 7(1), 1-9.

Anwar, E., \& Ahmar, F. (2013). Socio economic status and its relation to academic achievement of higher secondary school students. IOSR Journal of Humanities and Social Sciences (IOSR-JHSS), 13(6), 13-20.

Asante, K. O. (2010). Sex differences in Mathematics performance among senior high students in Ghana. African Journal Online (AJOL), 8(2), 3279-3289. https://doi.org/10.4314/gab.v8i2.61947

Ashikhia, D. A. (2010). Students and teachers' perception of causes of poor academic performance in Ogun State secondary schools (Nigeria): Implication for counseling for national development. European Journal of Social Sciences, 11(3), 364-369. Retrieved from http://www.Eurojournal.com/ejss

Awofala, A. O. A. (2007). Women and the learning of Mathematics. African Journal of Historical Sciences, 3 , 195-213.

Awofala, A. O. A. (2011). Is gender a factor in Mathematics performance among Nigerian senior secondary students with varying school organization and location? International Journal of Mathematics trends and Technology, 2(3), 17-21.

Baker, D. P., \& Jones, D. P. (1993). Creating gender equality: Crossnational gender stratification and Mathematics performance. Sociology of Education, 66(2), 91-103. https://doi.org/10.2307/2112795

Barry, J. (2006). The effect of socio-economic status on academic achievement (Master's thesis, Wichita State University, Kansas, United State of America).

Bassey, S. W., Joshua, M. T., \& Asim, A. E. (2008). Gender differences and Mathematics achievement of rural senior secondary students in Cross River State, Nigeria. Paper presented at the Third International Conference to review research in Science. Technology and Mathematics Education, Mumbai, India. Retrieved from http://www.hbose.tifr.res.in/epistem/episteme-3.pdf

Boardman, S., Herrington, C., \& Horowitz, S. (1987). Successful women: A psychological investigation of family, class, and education. In B. Gutek, \& L. Larwood (Eds.), Women's career development. Beverly Hills: Sage.

Bosede, A. F. (2010). Influence of sex and location on relationship between student problems and academic performance. The social sciences, 5(4), 340-345. https://doi.org/10.3923/sscience.2010.340.345

Bronfenbrenner, S. Y. (2005). Self-concepts, domain value and self-esteem: Relations and changes at early adolescence. Journal of Personality, 59(1), 224-232.

Campbell, P. B. (1995). Redefining the "girl problem" in Mathematics. In W. G. Secada, E. Fennema, \& L. B. Adjian (Eds.), New direction for equality in Mathematics education (pp. 225-241). Cambridge: Cambridege University Press.

Cohen, L., Manion, L., \& Morrison, K. (2011). Research Methods in Education (7th ed.). London: Routledge Taylor \& Francis Group.

Dhanalakshmi, K., \& Vijay, K. C. (2012). An exploratory study on rural and urban schools-a general view. International Journal of Evaluation and Measurement Research (IJEMR), 2(8), 1-7.

Eamon, M. K. (2005). Social-demographic, school, neighborhood, and preventing influences on academic achievement of Latino young adolescents. Journal of Youth and Adolescence, 34(2), 163-175. https://doi.org/10.1007/s10964-005-3214-x

Education resource Centre. (2014). An overview of the state of basic and secondary education in Delta State [Bronchure]. Delta State Ministry of Basic and Secondary Education: Asaba, Nigeria.

Enu, J., Agyman, O. K., \& Nkum, D. (2015). Factors influencing students' Mathematics performance in some selected colleges of education in Ghana. International Journal of Education Learning and Development, $3(3), 68-74$. 
Eric, S. (2005). The role of supportive school environment in promoting success: Getting results, development safe and healthy kids update 5. Student Health, Supportive Schools, and Academic Success, 3. Retrieved from http://www.collaborativeclassroom.org/research

Ezeudu, F. O., \& Obi, T. N. (2013). Effect of gender and location on students' achievement in chemistry in secondary schools in Nsukka Local Government Area of Enugu State, Nigeria. Research on Humanities and Social Sciences, 3(15), 50-55.

Ezeudu, S. A. (2013). Classroom environment as correlate of students' cognitive achievement in senior secondary school Geography. The Journal of the World Council for Curriculum and Instruction (WCCI) Nigeria, 4(2), 65-73.

Ezeudu, S. A., Gbendu, G. O., \& Umeifekwem, J. E. (2014). School location resus academic achievement in geography: Does reflective inquiry instructional techniques has effect? PAR/PEX. Indian Journal of Research, 3(9), 209-216.

Fatima, R. (n.d.). Role of Mathematics in the development of society.

Federal Republic of Nigeria. (2004). National Policy of Education.

Fenemma, E. (2000). Gender and Mathematics: What is known and what I wish was known? Paper prepared for the Fifth Annual Forum of the National Institute for Science Education, Detriot, Michigan. Retrieved from http://archive.wceruw.org/nice/News_Activities/Forums/Fennemapaper.htm

Fennema, E., \& Leder, C. G. (1990). Mathematics and Gender. Teachers College press. Columbia University, Columbia.

Forgasz, H. J., Leder, C. G., \& Vale, C. (2000). Gender and Mathematics: Changing perspective. In K. Owens, \& J. A. Mousley (Eds.), Research in Mathematics Education in Australasia, 1996-1999.

Fullwood, H., Gates, G., Pancake, A., \& Schroth, G. (2001). Rural and urban America. Rural Special Education Quarterly, 20, 1-12.

Ghaemi, F., \& Yazdanpanh, M. (2014). The relationship between socio-economic status and academic achievement in the EFL classroom among Iranian University Students. European Journal of English Language and Literature Studies, 2(1), 49-57.

Ghazi, S.R., Nawaz, K., Shahzad, S., Shahzada, G., \& Rukhsar, M. (2013). Relationship between parents' socio-economi status and their children academic performance. International Review of Social Sciences and Humanities, 5(2), 58-65.

Graetz, B. (1995). Socio-economic status in education research and policy. In J. Ainley et al. (Eds.), Socio-economic status and school education DEET/ACER. Canberra.

Greenwald, R., Hedhes, L. V., \& Laine, R. D. (1996). The effect of school resources on student achievement. Review of Educational Research, 66(3), 361-396. https://doi.org/10.3102/00346543066003361

Hartley, B. L., \& Sutton, R. M. (2013). A stereotype threat account of boys' academic underachievement. Child Develop, 84(5), 17/6-1733. https://doi.org/10.1111/cdev.12079

Hill, N.E., Castellino, D.R., Lansford, J.E., Nowlin, P., Dodge, K.A., Bates, J.E., \& Pettit, G.S. (2004). Parent academic involvement as related to school behaviour, achievement, and aspirations: demographic variations across adolescence. Child Develop, 75(5), 1491-1509. Doi:10.1111/j.1467-8624.00753.x

Hochschild, J. L. (2003). Social class in public schools. Journal of Social Issues, 59(4), 821-840. https://doi.org/10.1046/j.0022-4537.2003.00092.x

Hom, E. J. (2013). What is Mathematics? Live Science. Retrieved from http://www.livescience.com/38936-Mathematics.html

Hyde, J. S. (1990). Meta-analysis and the psychology of gender differences. The University of Chicago Press Journals, 16(1), 55-73. https://doi.org/10.1086/494645

Hyde, J. S., \& Mertz, J. E. (2009). Gender, culture, and Mathematics performance. In R. Schekman (Ed.), Proceedings of the National Academy of Sciences of the United States of America, 106(22), 8801-8807. https://doi.org/10.1073/pnas

Idialu, J. O. (2013). Influence of gender school location on students' attitude on academic achievement in basic technology in Delta State (Ph.D. thesis, University of Nigeria, Nsukka, Nigeria). 
Jeynes, W. H. (2002). Examining the effects of parental absence on the academic achievement of adolescents: the challenge of controlling for family income. Journal of Family and Economic Issues, 23(2), 189-210. https://doi.org/10.1023/A:1015790701554

Johnson, A. B. (2006). School mapping and resource supply as correlates of students' academic achievement in Kwara State secondary schools (Ph.D. thesis, University of Ibadan, Ibadan, Nigeria).

Jungwirth, H. (1991). Interaction and gender-findings of micro-ethnographic approach to classroom discourse. Educational Studies in Mathematics, 22(1), 263-284. https://doi.org/10.1007/BF00368341

Kerlinger, F. N., \& Lee, H. B. (2000). Foundations of behavioural research (4th ed.). United Kingdom: Cengage Learning.

Kiptum, J. K., Rono, P. K., Too, J. K., Bali, B. K., \& Too, J. (2013). Effects of students' gender on Mathematics performance in primary schools in Keiyo South District, Kenya. International Journal of Scientific and Technology research, 2(6) 247-252.

Lewin, K. (2009). Field theory and experiment in social psychology. American Journal of Sociology, 44(6), 868-896. https://doi.org/10.1086/218177

Lipsey, M. W., \& Wilson, D. B. (2001). Practical meta-analysis [e-book]. Retrieved from http|://www.worldcat.org/title/practical-meta-analysis/OC/C/49415119

Location (2016). In Merriam-Webster's online dictionary. Retrieved from $\mathrm{http} / / /$ merriam-webster.com/dictionary/location

Machebe, C. H., \& Odozi, I. C. (2014). Influence of parental socio-economic status on academic achievement of students in selected schools in Nigeria. A case study of Enugu State. Journal of Education and Practice, $5(2), 105-110$.

Machin, S., \& Pekkarinen, T. (2008). Global sex. Difference in test score variability. Jordanian Journals of Science, 322(5906), 1331-1332. https://doi.org/10.1126/science.1162573

Mahlomaholo, S., \& Sematle, M. (2005). Gender differences and black students' attitude towards Mathematics in selected high schools in South Africa. In J. T. Ajai (Ed.), Educational Studies in Mathematics Journal, 25, 209-216.

Mathematical Association of Nigeria. (2013, September 6). Communiqué of the $50^{\text {th }}$ annual conference of the mathematical association of Nigeria. Premium Times. Retrieved from http://www.premiumtimesng.com/tag/mathematical-association-of-nigeria

McNeal, R. B. (2001). Differential effects of parental improvement on cognitive and behavioural outcomes by $\begin{array}{llllll}\text { socio-economic status. Journal of } & \text { Socio-economics, } & 30(2), & 171 .\end{array}$ https://doi.org/10.1016/S1053-5357(00)00100-1

Mullis, I. V. S., Martin, M. O., Fierros, E. G., \& Stemler, S. E. (2000). Gender difference in achievement. IEA's Third International Mathematics and Science Study (TIMSS). International Association for the Evaluation of Educational Achievement, International Study Centre, Lynch School of Education, Boston College, Chestnut Hill, MA, USA.

National Geographic Society. (2016). Encyclopedia entry: urban and rural areas. In vocabulary. Retrieved from http://nationalgeographic.org/encyclopedia/urban- rural/area

Nwokocha, A. C., \& Amadike, N. N. F. (2005). A comparative study of academic performance in public and private secondary schools in rivers State, Nigeria. Journal of Educational Administration and Planning, $5(2), 188-191$.

Nworgu, B. G. (2015) Educational Research: basic issues and methodology (3rd ed.). Nsukka: University Trust.

Odeh, R. C., Oguche, O. A., \& Ivagher, E. D. (2015). Influence of school environment on academic achievement of students in secondary schools in Zone "A" Senatorial District of Benue State, Nigeria. International Journal of Recent Scientific Research, 6(7), 4914-4922.

Ogege, S. O. (2011). Gender role differentiation and social mobility of women in Nigeria. Journal of Social Science, 27(1), 67-74.

Ojoawo, A. O. (2014). A study of factors responsible for negative academic achievement in secondary schools in Oyo State. AJEM, 6(1 and 2), 180-188.

Okoiga, C. K. (2013). The impact of students' socio-economic background on academic performance in 
universities, a case of students in Kisii University College, Kenya. American International Journal of Social Sciences, 2(2), 38-46.

Okojie, C. O. (2004). The role of school in a changing society.In C. O. Okojie (Ed.), Foundations of Education. Benin City: Ethiope Pub. Corp.

Omoegun, M. (2007). Effect of parental socio-economic status on parental care and social adjustment in the UBE programme in Lagos State. Implication for counseling. International Journal of Educational Research, $3(2), 81-87$.

Onah, E. F. (2011). Influence of sex and school location on students' achievement in agricultural science. African Journal of Science, Technology and Mathematics Education, 1(1), 96-101.

Oni, A. A. (2007). Socio-economic status as predictor of deviant behaviours among Nigerian secondary school students. International Journal of Educational Research, 3(2), 225-236.

Onuoha, J. C. (2011). Influence of school location on students' achievement in social studies using concept mapping as an instructional strategy. Nigerian Social Science Education review (NSSER), 3(1), 116-126.

Onyeagu, O. O. (2005). A study of some factors affecting physics achievement in some secondary schools in Edo State (Master's thesis, University of Ibadan, Ibadan, Nigeria).

Opolot-Okurot, C. (2005). Educational Research: basic issues and methodology (3rd ed.). Nsukka: University Trust.

Orji, E. I. (2013). Effect of cognitive conflict instructional model on students' conceptual change and attention in temperature and heat (Master's thesis, University of Nigeria, Nsukka, Nigeria).

Orlu, C. (2013). Environmental influence on the academic performance of secondary school students in Port Harcourt Local Government Area of Rivers State. Journal of Economics and Sustainable Development, 4(12), 34-38.

Orubu, M. E. N. (2007). Influence of gender and socio-economic factors on performance in Mathematics among students in Ethiope East Local Government Area (Master's thesis, Delta State University, Abraka, Nigeria).

Osadebe, P. U. (2013). Assessment of students' perception on population control measures. British Journal of Advance Academic Research, 2(1), 95-103.

Osadebe, P. U. (2015a). Construction of valid and reliable test for assessment of students. Journal of Education and Practice, 6(1), 51-56.

Osadebe, P. U. (2015b). Assessment of teachers continuous assessment practice in line with education policy in primary schools. International Journal of Education and Research, 3(3), 171-180.

Osadebe, P. U. (2015c). Comparative analysis of senior secondary school students performance with school-based assessment scores of continuous assessment and promotion examination in Delta State. International Journal of Education, 7(1), 154-163. https://doi.org/10.5296/ije.v7i1.7112

Osadebe, P. U. (2016). Continuous assessment in schools. A seminar paper presented at Delta State University, Abraka.

Owoeye, J. S., \& Yara, P. O. (2011). School Location and academic achievement of secondary schools in Ekiti State, Nigeria. Journal of Asian Social Science, 7(5), 170-175. https://doi.org/10.5539/ass.v7n5p170

Perie, M., Moran, R., \& Lutkus, A.D. (2005). NAEP 2004 tends in academic progree: three decades of students performance in reading and Mathematics. National Center for Educational statistics: Washington D.C., $1-48$.

Reeves, E. B., \& Bylund, R. A. (2005). Are rural school inferior to urban schools? A multilevel analysis of school accountability trends in Kenturky. Journal of rural Sociology, 70(3), 360-386. Retrieved from http://agris.fao.org/aos/ records /us20 1301027798

Romanes, G. J. (1887). Mental differences between men and women. Science, 100(2589), 123-124. https://doi.org/10.1126/science

Rothman, A. (2003). The Changing influence of socioeconomic status on student achievement: Recent evidence from Australia. Paper presented to the annual meeting of the American research Association, Chicago. Retrieved from http://research.acer.edu.au/Lsay_confernce/3.

Salman, M. F., Mohammed, A. S., Ogunlade, A. A., \& Ayinla, J. O. (2012). Causes of mass failure in senior 
school certificate Mathematics examinations as viewed by secondary school teachers and students in Ondo, Nigeria. Journal of Education and Practice, 3(8), 79-88.

Spinath, B., Freudenthaler, H. H., \& Neubauer, A. C. (2010). Domain specific school achievement in boys and girls as predicted by intelligence, personality and motivation. Pers. individ. differ., 48, 481-486. https://doi.org/10.1016/j.paid.2009.11.028

Sunday, A. A. (2012). The relationship among school environment, student approach to learning and their academic achievement in senior secondary school in physics. International Journal of Educational Research and technology, 3(1), 67-78.

Turnbull, J., Lea, D., Parkinson, D., Phillips, P., Francis, B., Webb, S., \& Bull, V. (Eds.). (2015). Oxford advanced learner's dictionary: International students edition (8th ed.) Oxford, England: Oxford University.

Udonsa, A. E., \& Udonsa, O. E. (2015). Factors affecting senior secondary certificate examination candidates' performance in Mathematics: A study of selected secondary schools in Yola South Local Government Area of Adamawa State, Nigeria. Journal of Sociology, Psychology and Anthropology in Practice, 7(2), 48-56.

Umameh, M. A. (2011). A survey of factors responsible for students' poor performance in Mathematics in senior secondary school certificate examination (SSCE) in Idah Local Government Area of Kogi State, Nigeria (Master's thesis, University of Benin, Benin City, Nigeria).

Usaini, M. I., \& Abubakar, N. (2015, September 6-7). The influence of school environment on academic performance of secondary school students in Kuala Terengganu, Malasia. Proceedings of ICIC2015-International Conference on Empowering Islamic Civilization in the $21^{\text {st }}$ Century, University Sultan Zainai Abidin, Malaysia (pp. 252-261). Retrieved from http://www.unisza.edu.my/icic/images/fullpaper/25_Mudassir_Ibrahim_Usaini.pdf

Vale, C. (2009). Trends and factors concerning gender and Mathematics in Australasia. Proceedings of the $11^{\text {th }}$ International Congress on Mathematical Education, International Commissionon Mathematical Instruction: Monterrey, Mexico. Retrieved from http://hdl.hamdle.net/10536/DRO/DU:30044045

Walden, R., \& Walkerdine, V. (1985). Girls and Mathematics from primary to secondary schooling. London: Heinemann.

Weis, M., Heikamp, T., \& Trommsdorff, G. (2013). Gender differences in school achievement: the role of self regulation. From psycho. https://doi.org/10.3389/fpsyg

William, D. (2013). Assessment: The bridge between teaching and learning. Voices from the Middle, 21(2), 15-20. https://doi.org/10.1057/9780230359284.0022

$\mathrm{Xu}$, J. (2009). School location, student achievement, and homework management reported by middle school students. School Community Journal, 19(2), 27-43. Retrieved form http://eric.ed.gov/?id=EJ867967

Yusaf, M. A., \& Adigun, J. T. (2010). The influence of school sex, location and type on students' academic performance. International Journal for Education, 2(2), 81-85. https://doi.org/10.1080/09751122.2010.11889992

Zappala, G., \& Considine, G. (2002). The influence of social and economic disadvantage in the academic performance of school students in Australia. Journal of Sociology, 38(2), 129-148. https://doi.org/10.1177/144078302128756543

Zhu, Z. (2007). Gender differences in mathematical problem solving patterns: A review of literature. International Education Journal, 8(2), 187-203.

\section{Copyrights}

Copyright for this article is retained by the author(s), with first publication rights granted to the journal.

This is an open-access article distributed under the terms and conditions of the Creative Commons Attribution license (http://creativecommons.org/licenses/by/4.0/). 